\title{
STRATEGI PUBLISITAS BUPATI TANAH LAUT MELALUI MEDIA SOSIAL FACEBOOK DALAM SIAGA DARURAT COVID-19 DI KABUPATEN TANAH LAUT
}

\author{
Lieta Dwi Novianti ${ }^{1)}$, Ade Nur Atika Sari ${ }^{2)}$, Kenny Yola Safitri ${ }^{3)}$ \\ ${ }^{12) 33}$ Universitas Islam Kalimantan MAB Banjarmasin \\ E-mai: adenuratikasari91@gmail.com
}

\begin{abstract}
ABSTRAK
Penelitian ini berjudul Strategi Publisitas Bupati Tanah Laut Melalui Media Sosial Facebook Dalam Darurat Siaga Covid-19 Di Kabupaten Tanah Laut Tujuan penelitian adalah untuk mengetahui bagaimana pemanfaatan strategi publisitas yang dilakukan oleh Bupati Tanah Laut guna meningkatkan kesadaran masyarakat tentang kondisi Darurat Siaga Covid-19 Di Kabupaten Tanah Laut dengan sub masalah: 1. Strategi publisitas yang digunakan oleh Bupati Tanah Laut dalam Darurat Siaga Covid-19 Di kabupaten Tanah Laut ? 2. Dampak informasi apa yang didapatkan oleh masyarakat melaui publisitas yang dilakukan Bupati tanah laut menggunakan Media Sosial Facebook? Metode penelitian ini menggunakan pendekatan deskriptif dengan jenis penelitian kualitatif. Data yang dikumpulkan dengan menggunakan data primer dan sekunder kepada 11 (sebelas) orang informan. Pengumpulan data menggunakan teknik wawancara dan dokumentasi. analisis data yang digunakan adalah reduksi data, penyajian data, analisis perbandingan dan penarikan kesimpulan. Hasil penelitian menunjukkan bahwa Strategi publisitas yang digunakan oleh Bupati Tanah Laut melaui Media Sosial Facebook adalah Pure Publicity atau publisitas Murni dan Tie-In Publicity atau publisitas yang memanfaatkan extraordinary news. Dampak Informasi yang diterima masyarakat melalui Media Sosial Facebook adalah meningkatnya kesadaran masyarakat dan lebih memahami kondisi darurat siaga covid-19 di kabupaten tanah laut serta mendapatkan infromasi yang kredibel dari Publisitas yang dilakukan oleh Bupati Kabupaten Tanah Laut.
\end{abstract}

Kata Kunci: Publisitas; Hubungan Masyarakat; Media Sosial; Facebook.

\section{PENDAHULUAN}

Komunikasi merupakan kegiatan yang dibutuhkan dalam kehidupan sehari-hari manusia. Komunikasi memainkan peran penting bagi manusia untuk dapat berinterkasi dan berhubungan satu sama lainnya. Melalui komunikasi seseorang dapat menyampaikan berbagai hal yang ada dipikirannya kepada orang lain sehingga mencapai suatu pengertian makna pesan yang sama. Makna pesan yang tersampaikan dengan baik dapat membuat tujuan penyampaian pesan seseorang tercapai. Komunikasi juga adalah suatu proses untuk mencapai saling pengertian, di mana komunikator dan audiens membuat, membagikan, dan bertukar pemikiran, opini, serta informasi.

Komunikasi efektif memerlukan pemahaman tentang komunikator, audiens, tujuan, pesan, dan cara yang paling efektif untuk mencapai hasil yang diinginkan. Komunikasi yang efektif membutuhkan pendekatan faktual dan aktual. Maksudnya komunikasi tidak bisa meninggalkan realita. Informasi juga tidak boleh basi atau ketinggalan zaman. Perlu penguasaan dan pemahaman komunikasi komprehensif. Artinya, pemahaman yang dilandasi kejujuran komunikasi dan komunikasi atas dasar hati nurani. Sikap dan

perasaan seseorang atau sekelompok orang dapat dipahami oleh pihak lain melalui komunikasi. Akan tetapi, komunikasi hanya akan efektif apabila pesan yang disampaikan dapat ditafsirkan sama oleh penerima pesan tersebut.

Pada abad 21 karena pertumbuhan komunikasi digambarkan mengalami perkembangan yang revolusioner, hal ini dikarenakan peningkatan teknologi komunikasi yang pesat seperti radio, televisi, telepon seluler, satelit jaringan komputer dan internet seiring dengan industrialisasi bidang usaha yang besar dan politik yang mendunia. Wearesosial Hootsuite (Januari, 2019) merilis riset pengguna media sosial di Indonesia telah mencapai 150 juta atau sebesar $56 \%$ dari total 12 populasi. Jumlah tersebut naik $20 \%$ dari survei sebelumnya. Sementara pengguna media sosial mobile (gadget) mencapai 130 juta atau sekitar $48 \%$ dari populasi. Berdasarkan laporan terbaru We Are Social, pada tahun 2020 disebutkan bahwa ada 175,4 juta pengguna internet di Indonesia. Pengguna Internet di Indonesia mengalami kenaikan sebesar $17 \%$ atau sekitar 25 
juta penduduk dari tahun sebelumnya. Berdasarkan total populasi Indonesia yang berjumlah 272,1 juta jiwa, maka itu artinya $64 \%$ setengah penduduk RI telah merasakan akses ke dunia maya. Dengan besarnya populasi, pertumbuhan pengguna internet juga sangat pesat, yang juga menjadi potensi yang lebih besar dalam penyebaran informasi yang lebih cepat. Media informasi Dunia saat ini sedang digemparkan dengan merebaknya virus corona yang telah menjadi pandemi global.

Berawal dari kota Wuhan, China, virus yang kemudian dikenal dengan nama covid-19 ini menyebar tidak hanya ke seantero negeri, tetapi seluruh penjuru dunia. Tidak ada satu pun negara yang terbebas dari ganasnya virus corona ini tak terkecuali di Indonesia. Satu per satu korban meninggal akibat terjangkit virus corona berjatuhan. Tak hanya puluhan, tetapi mencapai ratusan korban jiwa yang ditemukan disetiap daerah. Jika diakumulasikan dalam skala Nasional, Satuan Tugas Penanganan Covid-19 melaporkan terjadi penambahan 4.106 kasus positif Covid-19 ditanggal 15 November 2020 sehingga total kasus positif Covid-19 yang terjadi di Indonesia menjadi 467.113 kasus, Satuan Tugas Covid-19 juga melaporkan total pasien yang berhasil sembuh sebanyak 391.991 orang dan total pasien terkonfirmasi positif yang meninggal dunia adalah 15.211 kasus kematian Penyampaian komunikasi selama masa krisis menjadi sangat penting dan harus diperhatikan dalam proses penyampaiannya.

Indonesia yang tengah dihadapkan dengan penyebaran penyakit Covid-19 yang begitu cepat telah membuat seluruh daerah di Indonesia bergerak sedemikian rupa untuk menangani masalah ini. penyebaran virus corona sudah sampai di Tiap Daerah di Indonesia dan Ketika situasi krisis ini diumumkan pastilah akan 3 berdampak pada melebarnya kepanikan. Di sinilah pentingnya seorang pemimpin dan komunikasi yang harus dibangun untuk menghadapi krisis yang tengah dihadapi. Suyatno (mediaindonesia, 2020) menyatakan bahwa Komunikasi memegang peranan penting dalam menghadapi ekspansi virus Corona secara rasional. Hal ini sangat menentukan dijadikannya momentum agar bangsa ini tangguh untuk menghadapi musuh yang sangat berbahaya itu.

Komunikasi yang baik dan efektif penting untuk menangkal kesimpangsiuran berita tentang covid-19 baik yang disengaja ataupun tidak. Pemahaman ini menunjukkan kepada kita akan urgensi komunikasi pemerintahan di semua lini. Salah satu yang erat dengan kondisi ini ialah kepiawaian dalam menangani kondisi seburuk apa pun termasuk penyampain korban terpapar corona. Kepiawaian seperti ini bisa mengubah sesuatu yang buruk menjadi lebih baik. Akhirnya kemungkinan terjadinya penyebaran berita hoaks yang mengancam jalannya program pemerintah menghadapi corona hingga berakibat pada keresahan yang lebih besar bisa dihindarkan. Karakter Keniscayaan komunikasi pemerintahan yang kuat melekat sebagaimana pada organisasi pada umumnya yang membutuhkan sejumlah karakter dalam melakukan komunikasi (Robbins, 1996). Di antara karakter itu, ialah kesadaran seluruh aparatur akan pentingnya komunikasi terkait corona. Keseluruhan ini menjadi titik penting keberhasilan sebuah komunikasi pemerintahan. Bukan lagi hanya urusan bagian humas yang harus memiliki kesadaran akan komunikasi pemerintahan sebagaimana yang dipahami selama ini. Dalam hal ini kepala daerah yang mengerti dengan kondisi masyarakat di daerahnya, diharuskan dapat menjadi komunikator yang baik dalam menyampaikan informasi tentang kisis yang tengah mereka alami, dengan menampilkan komitmen dan dedikasi serta menunjukkan Kepemimpinan disuatu daerah yang terdampak, agar masyarakat menganggap bahwa sumber yang diberikan sanggat kredibel. Kepala daerah sendiri harus Memahami kebutuhan informasi dari audiens akan membantu perencanaan 4 menjalankan respon komunikasi yang efektif. Komunikator profesional akan mengidentifikasi atau menargetkan audiens sebelum memulai komunikasi. Penyampaian informasi yang paling memungkinkan selama masa pandemi ini adalah dengan mempublikasikan informasi melalui media, selain minim biaya atau bahkan cenderung tanpa biaya, dapat memberikan keuntungan kepada pelaku maupun medianya.

\section{Perumusan Masalah}

Rumusan masalah berdasarkan latar belakang yang telah di uraikan diatas adalah sebagai berikut:

1. Bagaimana Strategi publisitas melalui media sosial facebook yang diimplementasikan oleh Bupati Tanah Laut dalam Darurat Siaga Covid-195

2. Apa Dampak Informasi yang didapat masyarakat dalam penggunaan media sosial facebook sebagai media publisitas Bupati Kabupaten Tanah Laut dalam Darurat Siaga Covid-19

\section{TINJAUAN PUSTAKA}

\section{Facebook}

Facebook diluncurkan pertama kali pada tanggal 4 Februari 2004 oleh Mark Zuckerberg (23), seorang programer komputer yang handal di Universitas Harvard. Pada awalnya, "Facebook" bernama "The Facebook", nama tersebut diambil dari nama lembaran dokumen yang dibagikan kepada setiap pelajar baru di Harvard yang menampilkan profil murid dan karyawan. Dalam 
waktu 24 jam sejak peluncurannya, 1.200 pelajar Harvard langsung bergabung. Satu bulan kemudian, lebih dari separuh pelajar di sana sudah mendata profilnya. 6 Bulan berikutnya, jaringan tersebut kemudian dengan cepat meluas ke sekolah lain di wilayah Boston (Boston College, Boston University, MIT, Tufts), Rochester, Standford, NYU, Northwestern, dan semua sekolah yang termasuk dalam Ivy League. Dalam waktu kurang dari empat bulan, 30 kampus telah tergabung dalam jaringan tersebut. Juni 2004 Facebook menyebar ke Stanford University di California.

Pada Desember 2004 facebook telah memperoleh 1 juta pemakai aktif. Pada 23 Agustus 2005 Zuckerberg membenahi situs facebook agar profil halamannya lebih bersahabat. 2 September 2005, Zuckerberg meluncurkan situs facebook khusus untuk anak-anak sekolah menengah atas. Hanya dalam waktu 15 hari sejak peluncurannya, sebagian besar sekolah di AS sudah menjadi anggotanya. Pada akhir tahun 2005, facebook telah mencakup sekitar 2.000 kampus dan 25.000 sekolah menengah atas di AS, Kanada, Inggris, Meksiko, Puerto Riko, Australia, Selandia Baru, dan Irlandia. Pada 27 Februari 2006, dia mulai 67 mengizinkan para mahasiswa yang menjadi pengguna situs ini untuk menambahkan siswasiswa SMA sebagai temannya. Pada April 2006, facebook pun masuk ke India melalui Institut Teknologi India dan Institut Manajemen India. Pada Juli 2006, facebook memperkenalkan layanan baru yang bisa memberikan pendapatan tambahan bagi perusahaan. Dengan menggandeng raksasa komputer, Apple Inc., mereka bekerja.

Publisitas

Publisitas berasal dari bahasa inggris, publicity yang artinya dalam Websters Tower Dictionary, quality of being public; written or photographic material having some news value and designed to promote the interest of someone or something (Kertapati, Departemen Penerangan RI, tanpa tahun: 7). Publisitas harus memiliki nilai berita untuk diketahui semua orang; baik tertulis atau fotografi. Kegiatan publisitas memiliki motifmotif tertentu, maka institusi harus memiliki desain atau langkah-langkah tertentu dalam usaha merencanakan dan menyusun pesan yang ingin disampaikan. Publisitas dari kacamata media massa adalah informasi yang disediakan oleh sumber luar yang digunakan oleh media karena informasi itu memiliki nilai berita (Kriyantono 2008: 41).

Institusi tak memberi harga untuk ini karena tidak meminta media untuk memuat. Publisitas adalah upaya institusi untuk 23 mendapatkan porsi 23 pemberitaan di media massa. Pada dasarnya publisitas berbicara mengenai informasi yang memiliki nilai berita dan direncanakan untuk kepentingan institusi. Publisitas adalah "Sejumlah informasi tentang sasaran, barang, atau organisasi yang disebarluaskan ke masyarakat melalui media tanpa dipungut biaya atau tanpa pengawas dari sponsor". Publisitas merupakan pelengkap yang efektif bagi alat promosi yang lain seperti periklanan, personal selling, dan promosi penjualan. Biasanya, media bersedia mempublisitas suatu cerita apabila materinyadirasakan cukup menarik atau patut dijadikan berita. (Swastha dan Irawan 2004:350)

Publicity is a non personal form of communication that seek to influence the attitudes, feelings and opinions of cutomers, noncustomers, stockholders, suppliers, employees, and political bodies about organization, which is a nonpaid form of non personal communication about the organization that is transmitted through a mass medium in the form of a news story. Obviously, marketers seek positive publicity. (J. Paul Peter dan James H.Donnelly Marketing Management knowledge and skill, 2008:112) yang artinya bahwa publisitas adalah bentuk non personal komunikasi yang berupaya untuk mempengaruhi sikap, perasaan, dan pendapat pelanggan, non pelanggan, pemegang saham, pemasok, karyawan, personal politik tentang organisasi, yang mana sifatnya tak berbayar melalui mass media dalam bentuk pemberitaan. Dan pastinya para pemasar menginginkan pemberitaan positif.

\section{Public Relation}

Public Relations adalah disiplin yang memandang dampak reputasi, dengan menambahkan pemahaman, dukungan, memengaruhi opini dan perilaku. Hal itu direncanakan untuk mempertahankan goodwill dan mutual understanding antara organisasi dan publiknya. Menurut Cutlip Center and Broom Public Relations (2009: 25) adalah, fungsi manajemen yang membangun dan mempertahankan hubungan yang baik dan bermanfaat antara organisasi dengan publik yang memengaruhi kesuksesan atau kegagalan organisasi. Public Relations berhubungan dengan reputasi, hasil yang dilakukan, dikatakan dan apa yang orang lain katakan tentang anda Sebagai profesi, dalam Pengantar Humas diajarkan, Public Relations dibagi menjadi tiga yakni professional skill (mendefinisikan masalah dan menyusun strategi), verbal skill (kemampuan lisan yang harus didukung dengan kemampuan menulis), social skill (kemampuan bersosialisasi dan menjaring koneksi). PR dalam 35 penelitian ini diteliti sebagai sumber daya manusia yang mampu diukur kinerjanya.

Menurut Wirawan (2009: 1) SDM merupakan sumber daya yang digunakan untuk menggerakkan dan menyinergikan sumber daya lainnya untuk mencapai tujuan organisasi. Tanpa SDM, sumber daya lainnya menganggur (idle) dan kurang bermanfaat dalam mencapai tujuan organisasi. Dalam Wirawan (2009: 9), kinerja 
memiliki hubungan kausal dengan kompetensi (competency atau ability). Kinerja merupakan fungsi dari kompetensi, sikap dan tindakan. Kompetensi melukiskan karakteristik pengetahuan, keterampilan, perilaku dan pengalaman untuk melakukan suatu pekerjaan atau peran tertentu secara efektif. Kompetensi dapat diartikan sebagai kewenangan untuk memutuskan sesuatu. Kompetensi PR sebagai sumber daya manusia berarti memiliki tanggungjawab demi tujuan tertentu yang diaplikasikan pada cara bekerjanya. Menurut Larissa Grunig dalam tulisannya yang berjudul Power in The Public Relations Department (Grunig 1992: 483), most PR are technically. They engage in typically journalistic act but they tend to remain 'outside' the door when those top-level decisions are being made.

\section{METODE PENELITIAN}

Pendekatan yang digunakan dalam penelitian ini adalah pendekatan kualitatif adalah suatu proses penelitian yang dilakukan secara wajar dan natural sesuai dengan kondisi objektif di lapangan tanpa adanya manipulasi (Zainal Arifin, 2009:140) Pendekatan kualitatif menekankan analisis proses dari proses berpikir secara induktif yang berkaitan dengan dinamika hubungan antar fenomena yang diamati, dan senantiasa menggunakan logika ilmiah (Imam Gunawan, 2013:80)

Menurut Bogdan dan Taylor yang dikutip oleh Lexy J. Moleong "Penelitian kualitatif adalah sebagai prosedur penelitian yang menghasilkan data deskriptif berupa kata-kata tertulis atau lisan dari orang-orang dan perilaku yang dapat diamati (Lexy Moleong, 2006:4) Jadi penelitian kualitatif adalah penelitian yang bermaksud untuk memahami fenomena tentang apa yang dialami oleh subjek penelitian misalnya perilaku, persepsi, motivasi, tindakan dan sebagainya, secara holistik dan dengan cara deskripsi dalam bentuk kata-kata dan bahasa, pada suatu konteks khusus yang alamiah dan dengan memanfaatkan berbagai metode alamiah, penelitian langsung kepada sumbernya tanpa melakukan jajak pendapat kepada orang banyak melalui kuisioner.

\section{HASIL DAN PEMBAHASAN}

Penyebaran virus covid-19 telah menjadi pandemi global yang Berawal dari kota Wuhan, China yang kemudian menyebar tidak hanya di Negara China saja, tetapi juga ke seluruh dunia termasuk Indonesia. Penyebaran virus covid-19 di Indonesia sendiri telah menyebar di setiap kota dan kabupaten termasuk di Kabupaten Tanah Laut. Ditemukan sejumlah masyarakat yang terpapar virus ini yang kemudian menyebar kesetiap kecamatan yang ada di kabupaten Tanah Laut. Pemerintah Kabupaten Tanah laut akhirnya menetapkan siaga darurat Covid-19 di Kabupaten Tanah laut sejak 16 Maret 2020, setelah sebelumnya diumumkan 3 masyarakat Tanah Laut yang dinyatakan positif terjangkit covid-19 pada tanggal 18 April 2020 yang kian hari makin 62 bertambah sehingga menciptakan khawatiran bagi masyarakat di Kabupaten Tanah Laut.

Dalam masa pandemi seperti ini masyarkat akan sulit mempercayai berita yang diberikan oleh media massa, oleh karena itu Pemerintah Daerah menjadi salah satu pihak yang dirasa sangat perlu meredam kekhawatiran masyarakat mengenai krisis yang sedang terjadi, Pemerintah Kabupaten Tanah Laut harus memiliki strategi untuk membangun dan meningkatkan kesadaran masyarakat terhadap bahaya penyebaran virus covid-19 di Kabupaten Tanah Laut yang dilakukan melalui Publisitas melalui Media Komunikasi. Media Komunikasi yang digunakan adalah melalui Media Sosial salah satunya Media Sosial Facebook. Publisitas sendiri bertujuan untuk meningkatkan kesadaran public dari produk dan layanan, upaya Pemerintah Kabupaten Tanah Laut untuk meningkatkan kesadaran melalui media ini adalah dengan mengupayakan memberikan informasi kepada masyarakat dan memberikan berita-berita positif di media sosial.

Produk dan layanan yang dimaksud dalam kondisi ini adalah menganai Siaga Daruat Covid19. Sehingga akhinya publik memiliki kesan yang baik dan meyakini bahwa perusahan/organisasi tersebut memiliki kredibilitas tinggi dan terpercaya, juga dalam memberi arahan kepada masyarakat agar turut serta membantu pemerintah memutus mata rantai penyebaran virus covid-19 yang kemudian akan meningkatakan kesadaran masyarakat mengenai penyebaran Virus Covid-19 di Kabupaten Tanah Laut.

Media Sosial Facebook menjadi salah satu media publisitas yang dirasa cukup efektif dibandingkan dengan media sosial lain, seperti yang di sampaikan pegawai bagian Prokopim M. Fahmi Hidayat: Bupati Tanah Laut dan Humas Kabupaten Tanah Laut memberikan informasi mengenai Covid-19 ini melalui Website Resmi Pemerintah Kabupaten dan beberapa sosial media seperti instagram dan facebook, tetapi untuk di Kabupaten Tanah Laut sendiri Media sosial 63 facebook bisa dibilang sebagai Media sosial yang merakyat, karena hampir semua kalangan di Tanah Laut menggunkan Facebook.

Legibilitas, yakni materi publisitas berupa bentuk tulisan yang dibuat untuk menyampaikan pesan mudah dipahami, dan cukup jelas diikuti oleh khalayak hal ini dapat ditunjukan melaui keterangan dipostingan yang langsung kepada tujuan penyampaian informasi tersebut tidak bertele-tele dan menggunakan bahasa yang mudah dipahami masyrakat. 
Hal ini juga disampaikan oleh Suparno kepala desa bukit mulia Penyampaian bapak kamta dan humas kabupaten tanah laut difacebook sangat mudah dipahami, jadi saya sendiri pun lebih mudah untuk menyampaikan kembali kepada orang lain. Makfud Prayoga juga menyatakan: Beritanya cukup mudah untuk dipahami dan dapat dipercaya, jadi kita tidak ragu dan bingung mengenai berita tentang covid ini.

Menyampaian Informasi kepada masyarakat luas melalui Media sosial Facebook pasti memberikan dampak, baik dampak negatit maupun positif bagi masyarakat luas dan juga pengguna sosial media tersebut. Publisitas Bupati Tanah Laut dalam darurat siaga Covid-19 melalui media sosial facebook dianggap sangat membantu masyarakat dalam 70 mencari informasi mengenai covid-19, karena kredibilitas yang dimilik oleh Bupati Tanah Laut itu sendri Suparno dalam wanwancara mengatakan Memang saya mencari informasi salah satunya juga dari facebook, termasuk di akun sosial medianya bupati dan humasnya, alasan ya karena akun tersebut kana kun resmi yang pemerintah dan akun probadi nya bupati, pasti infromasi yang diberikan juga terpercaya dan pasti dapat dipertanggung jawabkan beritanya.

Hal ini juga disebutkan oleh Tri Utami Tidak ada alasan kita tidak mempercayai akun nya bupati dan akun humas masa pandemi seperti sekarang kalau kita tidak percaya dan menerima infromasi dari akun-akun itu di mana lagi kita bisa mencari infromasi mengenai covid di tanah laut Tak jauh berbeda yang disampaika novika Putri Aku sendiri merasa terbantu sekali karena kadang juga merasa khawatir mengenai penyebaran covid di tanah laut tetapi melihat Bupati Tanah Laut yang sering terlihat mengunjungi pasien yang sudah sembuh dan mengunjungi masyarakat yang terdampak covid-19 ini sedikit banyak aku jadi tenang karena tau bahwa pemerintah sangat memperhatikan masyarakatnya.

Tak jauh berbeda yang disampaikan Novika Putri Aku sendiri merasa terbantu sekali karena kadang juga merasa khawatir mengenai penyebaran covid di tanah laut tetapi melihat Bupati Tanah Laut yang sering terlihat mengunjungi pasien yang sudah sembuh dan mengunjungi masyarakat yang terdampak covid-19 ini sedikit banyak aku jadi tenang karena tau bahwa pemerintah sangat memperhatikan masyarakatnya.

\section{PENUTUP}

\section{Kesimpulan}

Publisitas merupakan salah satu strategi yang diterapkan oleh Buapati dan Pemerintah Kabupaten Tanah Laut dalam darurat siaga Covid19 di Kabupaten Tanah Laut . Konsep publisitas yang diimplementasikan oleh Bupati
Tanah Laut adalah bentuk publisitas murni (Pure Publicity) dan Publisitas yang memanfaatkan extraordinary news (tie-in publicity). Karena dari banyak nya postingan yang di upload di media sosial facebook Kamta dan humas Kab. Tanah Laut menunjukan kegiatan yang biasa dilakukan Bupati sebagai kepala daerah dan juga keterlibatan Bupati Tanah Laut dalam beberapa kegiatan menghasilkan publisitas yang menguntungkan dalam menaikan kredibilitas. Media sosial menjadi wadah utama dalam publisitas Bupati Tanah Laut ialah Media sosial facebook.

Publisitas yang dilakukan bupati dan pemerintah kabupaten tanah laut dalam daruart siaga covid-19 di Kabupaten Tanah laut mencakup unsur-unsur dari publisitas sebagai berikut : 1 . Adanya sumber publisitas yang dalam hal ini sumber publisitasnya adalah kegiatan bupati tanah laut dalam masa siaga darurat covid-19 di Kabupaten Tanah Laut 2. Adanya message atau pesan yang bersifat informatif, persuasif, konstruktif, destruktif tentang sesuatu baik orang, even, barang, jasa, aktivitas, dan peran 3. Adanya media yang digunakan yaitu ruang publik, ruang media soial facebook 4. Ada managemen kegiatan/aktifitas, sebelum menyampaikan infromasi mengenai kegiatan dan himbauan kepada masyarakat mengenai penyebaran covid-19, sebelumnya akan dilakukan diskusi dan perencanaan, agar infromasi yang disampaikan tepat sasaran dan tidak menimbulkan kekhawatiran baru bagi masyarakat. 75765 .

Adanya audiens (Khalayak) adalah masyarakat luas, khususnya masyarakat Kabupaten Tanah Laut. Dampak informasi yang didapatkan masyarakan melaui publisitas yang dilakukan oleh Bupati kabupaten Tanah Laut mengenai darurat siaga covid -19 dapat dilihat pada masyarakat yang tertarik untuk ikut serta memabagikan infromasi yang disampaikan oleh Bupati Tanah Laut. Kredibilitas dan tanggung jawab yang disampaikan pada postingan tersebut menjadi salah satu alasan utama masyarakat menggunakan kedua akun tersebut untuk salah satusarana mencariinfromasi mengenai covid-19 dan juga Postingan Media Sosial Facebooknya mampu membuat masyarakat lebaih sadar dan mengerti terhadap Kondisi Siaga darurat Covid-19 di kabupaten Tanah Laut. Hal ini juga berdampak pada banyaknya masyarakat yang ikut serta mengingatkan keluarga dan kerabatnya mengenai siaga covid-19 di Kabupaten Tanah Laut.

\section{Saran}

1. Beberapa saran yang peneliti bisa jadikan masukan, saran dari hasil penelitian ini adalah sebagai berikut 1 . Penelitian ini hanya meneliti Strategi publisitas di satu media sosial Facebook saja. Diharapkan dalam Penelitian berikutnya mampu membandingkan konsep 
MUTAKALLIMIN; Jurnal Ilmu Komunikasi

Vol 4 No 2 November 2021

dan strategi publisitas di media komunikasi yang lainnya. Dan lebih ditekankan kepada tingkat kepuasan masyarakat pada upaya Pemerintah Kabupaten Tanah Laut dalam penanggulangan covid-19 menggunakan teknik pengumpulan data dan pengisian kuisoner sehingga bersifat obyektif .

2. Bagi pengguna media sosial diharapkan dapat memilih infromasi yang kredibel dan dapat dipertanggungjawabkan, dan memilih akunakun apa saja yang dapat dijadikan media informasi sebelum membagikannya kembali baik di sosial media maupun langsung menyampaikan nya secara langsung kepada orang lain, agar tidak terjadi kebingungan dan penyebaran berita yang tidak benar.

\section{REFERENSI}

Darmastuti, Rini. 2013. Media Relations: Konsep, Strategi, Aplikasi. Yogyakarta. Pustaka Belajar.

Departemen Pendidikan dan Kebudayaan. 1995. Kamus Besar Bahasa Indonesia, Cetakan ke-8. Jakarta. Balai Pustaka Hidayat, Dasrun M.I.Kom. 2014.

Media Public Relations: Pendekatan Studi Kasus Cyber Publik Relations Sebagai Metode Kerja PR Digital. Yogyakarta. Graha Ilmu. Hidayat, Dedi N. 2003.

Paradigma dan Metode Penelitian Sosial Empirik Klasik. Jakarta.

Departemen Ilmu Komunikasi FISIP Universitas Indonesia. Jefkins, Frank. 2003. Public Relation. Jakarta.

Erlangga. Kriyantono, Rahmat. 2012. PR Writing: Teknik Media Public Relation dan Publisitas Korporat. Jakarta. Kencana. Kriyantono, Rachmat. 2009.
Teknik Praktis Riset Komunikasi. Jakarta.

Kencana Prenada Media. Liliweri, Alo. 2011. Komunikasi Serba Ada Serba Makna. Jakarta. Kencana Prenada Media. Moleong, Lexy J. 2004.

Metodologi Penelitian Kualitatif (Edisi Revisi). Bandung. Remaja Rosdakarya. Mulyana, Deddy. 2003.

Metodologi Penelitian Kualitatif. Bandung. PT Remaja Rosdakarya. Nazir, Moh. 2003. Metode Penelitian. Jakarta. Ghalia Indonesia. Nazir, Muhammad. 1988.

Metode Penelitian. Jakarta. Ghalia Indonesia. Saputra, Wahidin \& Nasrullah, Rulli. 2014. Public Relations 2.0: Teori dan Praktik Public Relations di EraCyber. Depok. Gramata Publishing. Suryabrata. 1963.

Metode Penelitian. Jakarta. CV Rajawali. Syafi'I, Inu Kencana. 2010. Ilmu Politik. Jakarta. PT Rineka Cipta.

Thubany, Syamsul Hady. 2005 Era Baru Demokratisasi Lokal Indonesia. Jogjakarta. Nuansa Aksara. West, Richard \& Turner. 2008. Teori Komunikasi, Analisis dan Aplikasi, Buku 1 ed. 3. Jakarta.

Salemba Humanika. Wiryanto. 2004.

Pengantar Ilmu Komunikasi. Jakarta. PT Grasindo.Internet

https://portal.tanahlautkab.go.id/halaman/detail/profil -daerah https://covid19.tanahlautkab.go.id/ 